\title{
Soluble carbohydrate content of ryegrass cultivars
}

\author{
H.S. EASTON ${ }^{1}$, A.V. STEWART ${ }^{2}$, T.B. LYONS $^{1}$, M. PARRIS ${ }^{2}$ and S. CHARRIER ${ }^{2}$ \\ ${ }^{1}$ AgResearch Ltd, Private Bag 11008, Palmerston North \\ ${ }^{2} P G G$ Wrightson Seeds, P O Box 939, Christchurch, New Zealand
}

sydney.easton@agresearch.co.nz

\begin{abstract}
A set of 18 ryegrass cultivars and breeders' lines, some selected for elevated concentrations of high molecular weight fructan, were compared for forage composition in mown row trials at two sites, in Canterbury and Manawatu. Cultivars varied significantly and consistently, with cultivars selected for elevated high molecular weight fructan showing consistently higher concentrations of these and total soluble carbohydrate, and lower concentrations of crude protein. Some recently developed New Zealand breeding lines are comparable with imported cultivars. Plant breeding has delivered cultivars distinctive for soluble carbohydrate concentration, and further enhancements are likely to be possible. Optimum target levels for soluble carbohydrate concentration are not yet clear.
\end{abstract}

Keywords: fructan, soluble carbohydrates, protein metabolism, forage quality, ryegrass breeding, cultivars

\section{Introduction}

Perennial ryegrass cultivars selected for enhanced concentrations of fructan have been available in New Zealand for several years. Fructans are high molecular weight sugars, and are an important component of the soluble carbohydrate (WSC) fraction of pasture grasses. Fructans play a part in regular carbohydrate metabolism of grasses, being synthesised from simple sugars produced by photosynthesis and then broken down as carbohydrate is mobilised (Pollock \& Cairns 1991). In leaf blades, fructan concentration shows a diurnal variation, building up through the day as photosynthate is temporarily stored and declining at night as photosynthate is mobilised and exported from the leaf. In the leaf sheath, crown and stems, fructans have a longer term storage function, and the concentration in the sheath is higher than in the blade.

WSC is the most readily digestible component of herbage, and higher concentrations in ingested herbage should favourably influence the balance of proprionate to acetate in the rumen (Beever 1993; Marley et al. 2007). Enhanced fructan concentration is expected to deliver a higher metabolisable energy (ME) content, if the increase in fructan is at the expense of components of lower density of digestible energy. This was the original intent of development of high fructan selections (Humphreys 1989), and higher ME is expected to translate directly to enhanced livestock production.

Attention is also directed to the rate of metabolism of fructan by the animal, and to the interaction in the animal of carbohydrate and protein metabolism (Beever 1993; Cosgrove et al. 2007; Edwards et al. 2007a; Edwards et al. 2007b; Pacheco et al. 2007). It is argued that higher content of readily available energy will enhance the efficiency of protein utilisation, and shift the partition of digested nitrogen, with more going to growth and production and less excreted as urea. This would have productivity benefits, and with less nitrogen lost to the soil and thence to the atmosphere would also reduce the environmental impact of the system. However, another point of view is that WSC content of fresh pasture is already high and contributes to sub-optimal rumen $\mathrm{pH}$ (Dewhurst \& Qiao 2007).

Cultivars developed by IBERS (formally IGER) in UK for enhanced concentration of fructan have been evaluated in UK and elsewhere in Europe. They show a higher concentration of fructan in herbage than other cultivars growing in the same conditions. Effects on livestock productivity are variable (Edwards et al. 2007b), with some data sets showing unequivocal benefit (Lee et al. 2001; Merry et al. 2006; Miller et al. 2001), others less so (Lee et al. 2002; Moorby et al. 2006; Taweel et al. 2005). For effects on nitrogen partitioning, it is suggested that carbohydrate to protein ratio may be more significant than carbohydrate alone (Cosgrove et al. 2007; Edwards et al. 2007a; Edwards et al. 2007b; Pacheco et al. 2007).

In New Zealand there have been few results published on field performance of cultivars selected for higher fructan concentration. This paper reports the results of trials at two locations, sampled throughout the year.

\section{Materials and Methods}

Cultivars developed by IBERS for enhanced herbage fructan concentrations, New Zealand cultivars and several New Zealand breeding lines (Table 2, collectively referred to as 'entries'), were sown in autumn 2007 in rows $2 \mathrm{~m}$ long at two sites, in Canterbury and Manawatu, in four replicates as randomised complete blocks. From spring 2007, fresh, disease-free herbage was harvested to $5 \mathrm{~cm}$ at several times through the year and freeze dried for analysis. Plots were maintained at moderate fertility with $20 \mathrm{~kg} / \mathrm{ha}$ nitrogen as urea applied after 
each harvest.

The Manawatu site $\left(40^{\circ} 35^{\prime} \mathrm{S}\right)$ experiences a milder climate than the Canterbury site $\left(43^{\circ} 38^{\prime} \mathrm{S}\right)$, with half the ground frosts ( $38 \mathrm{cf} 70)$ and milder mean minimum winter temperature $\left(5.2^{\circ} \mathrm{C}\right.$ c.f. $2.0^{\circ} \mathrm{C}$, NIWA 2009). It also receives greater rainfall $(966 \mathrm{~mm} \mathrm{cf} 667 \mathrm{~mm})$ and experiences less severe summer water stress.

In Manawatu, plots were harvested when regrowth was $10-15 \mathrm{~cm}$, between 1 and $2 \mathrm{pm}$. No samples were harvested between November 2007 and May 2008 (Table 1), but sampling continued through early summer 2008 and autumn 2009. Samples from replicates were bulked for each entry and bulk samples immediately snap-frozen in liquid nitrogen. At the last harvest, in April 2009, samples from each plot were processed for analysis. In Canterbury, harvests were taken when regrowth was 15 $20 \mathrm{~cm}$, between $10 \mathrm{am}$ and noon. Individual plot samples were held on ice then frozen. Samples were harvested from October 2007 until August 2008 (Table 1).

Freeze-dried samples were ground and scanned using a MPA Brucker NIR Spectrophotometer, to estimate crude protein, fructan and total WSC. Fructan and total WSC estimates were derived from a calibration

Table 1 Mean concentrations (\% dry weight) of fructan, total water soluble carbohydrate (WSC) and crude protein of 18 cultivars and breeding lines for each harvest at two sites (Canterbury and Manawatu).

\begin{tabular}{llll}
\hline Canterbury & Fructan & Total WSC & Crude protein \\
\hline 18-Oct-07 & 7.8 & 24.8 & 19.1 \\
15-Nov-07 & 10.8 & 28.9 & 17.3 \\
11-Jan-08 & 3.2 & 16.6 & 21.5 \\
28-Feb-08 & 12.7 & 27.6 & 11.3 \\
27-Mar-08 & 13.7 & 30.0 & 11.5 \\
13-Apr-08 & 2.9 & 22.7 & 22.2 \\
6-Aug-08 & 10.9 & 26.7 & 14.9 \\
29-Sep-08 & 7.8 & 25.4 & 17.1 \\
\hline Manawatu & Fructan & Total WSC & Crude protein \\
\hline 17-Sep-07 & 4.2 & 20.0 & 22.5 \\
9-Oct-07 & 2.2 & 19.0 & 26.6 \\
8-Nov-07 & 7.3 & 24.3 & 20.9 \\
2-May-08 & 3.0 & 16.6 & 19.1 \\
9-Jun-08 & 2.3 & 17.2 & 28.5 \\
15-Sep-08 & 4.4 & 20.6 & 23.4 \\
10-Oct-08 & 8.7 & 22.9 & 17.5 \\
25-Nov-08 & 16.1 & 29.8 & 11.3 \\
22-Dec-08 & 6.2 & 16.6 & 18.2 \\
17-Apr-09 & 8.2 & 21.9 & 15.6 \\
\hline & & & \\
\hline
\end{tabular}

previously developed from wet chemistry analysis of fresh ryegrass herbage harvested in Manawatu and Canterbury. Crude protein was estimated from the standard calibration supplied with the machine.

For each Canterbury harvest, and for the April 2009 harvest in Manawatu, a two-way ANOVA was completed for each forage component with entry a fixed main effect. An overall split-plot ANOVA for Canterbury data was completed with harvests treated as blocks and physical plots as the sub-plots. For Manawatu, an overall two-way ANOVA was completed with harvest and entry as fixed effects. An analysis of all harvest means was completed with site, harvest and entry as main effects.

\section{Results}

Mean concentrations of fructan, total WSC and crude protein varied widely between harvests (Table 1 and Fig. 1). Fructan and total WSC harvest concentrations were correlated, and crude protein concentrations varied inversely with them. For the Canterbury site, there was a set of regular sampling through the season. The data set does not support any firm conclusions about pattern of variation through the year, but fructan concentrations in November (two data points from Manawatu, as well as the Canterbury point) were higher than preceding or following harvests. There are no corresponding harvests from Manawatu to compare with the elevated concentrations recorded at the Canterbury site in late summer.

Carbohydrate concentrations (fructan and total) were on average higher and protein concentrations lower at

Figure 1 Respective mean fructan concentrations (\% of dry weight) by harvest comparing diploid entries selected for enhanced WSC with those not so selected (non). C - Canterbury site; M - Manawatu site.

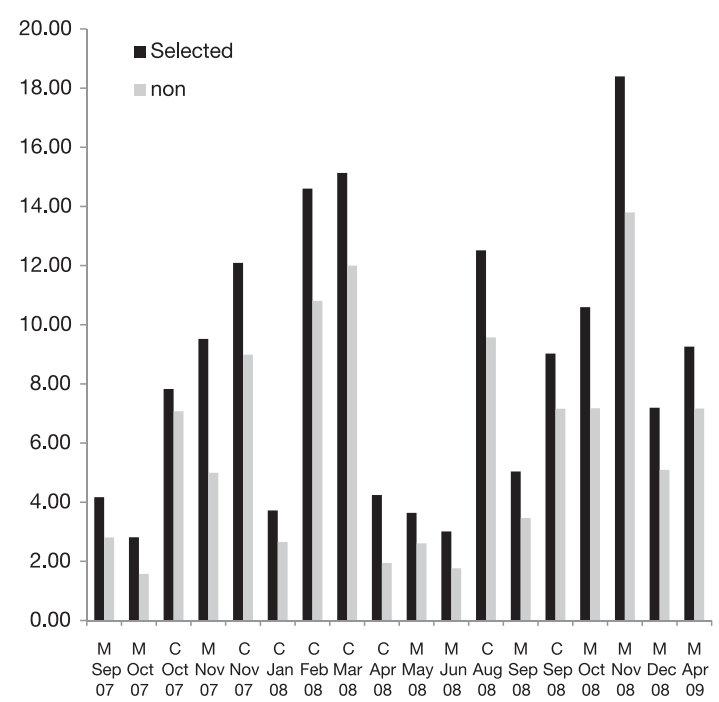


Table 2 Mean concentrations (\% dry weight) of fructan, total water soluble carbohydrate (WSC), crude protein and the ratio of total WSC to protein for 18 cultivars and breeding lines at two sites (Canterbury and Manawatu) (EL1 etc are experimental breeding lines; $4 \mathrm{X}$ designates tetraploid).

\begin{tabular}{|c|c|c|c|c|c|c|c|c|c|}
\hline & \multirow[t]{2}{*}{ Class $^{1}$} & \multicolumn{4}{|c|}{ Canterbury } & \multicolumn{4}{|c|}{ Manawatu } \\
\hline & & Fructan & Total WSC & $\begin{array}{l}\text { Crude } \\
\text { protein }\end{array}$ & $\begin{array}{r}\mathrm{CHO}: \\
\text { protein }\end{array}$ & Fructan & Total WSC & $\begin{array}{l}\text { Crude } \\
\text { protein }\end{array}$ & $\begin{array}{l}\mathrm{CHO}: \\
\text { protein }\end{array}$ \\
\hline Aberavon & IBERS & 9.06 & 25.60 & 17.94 & 1.52 & 8.16 & 22.92 & 19.85 & 1.45 \\
\hline Aberdart & IBERS & 8.78 & 25.64 & 17.74 & 1.62 & 6.77 & 21.14 & 19.71 & 1.20 \\
\hline Abermagic & IBERS & 11.00 & 27.99 & 15.96 & 1.92 & 9.23 & 24.64 & 18.22 & 1.59 \\
\hline Aberstar & IBERS & 8.98 & 25.67 & 17.41 & 1.61 & 7.16 & 22.29 & 19.74 & 1.22 \\
\hline Banquet 4X & $\mathrm{NZ}$ & 6.31 & 21.91 & 18.63 & 1.26 & 3.85 & 17.41 & 22.65 & 0.82 \\
\hline Bealey $4 \mathrm{X}$ & $\mathrm{NZ}$ & 8.01 & 24.38 & 17.51 & 1.55 & 6.34 & 21.19 & 20.06 & 1.25 \\
\hline Expo & NZS & 9.69 & 26.58 & 15.16 & 1.88 & 6.70 & 21.68 & 19.90 & 1.32 \\
\hline Horizon 4X & $\mathrm{NZ}$ & 8.08 & 24.30 & 17.62 & 1.56 & 6.77 & 22.41 & 20.20 & 1.21 \\
\hline Impact & $\mathrm{NZ}$ & 8.57 & 25.00 & 16.18 & 1.64 & 3.98 & 17.54 & 21.26 & 0.92 \\
\hline Samson & $\mathrm{NZ}$ & 7.25 & 23.40 & 17.06 & 1.56 & 4.87 & 18.91 & 21.73 & 0.93 \\
\hline EL1 & EXP & 6.85 & 23.04 & 15.95 & 1.53 & 5.32 & 19.30 & 20.84 & 1.07 \\
\hline EL2 & EXP & 7.51 & 23.22 & 17.74 & 1.40 & 5.29 & 18.55 & 22.03 & 0.96 \\
\hline EL3 & EXP & 7.81 & 23.80 & 16.58 & 1.59 & 5.25 & 19.20 & 20.73 & 1.01 \\
\hline EL4 & EXPS & 10.67 & 28.41 & 16.71 & 2.01 & 6.78 & 22.25 & 20.43 & 1.20 \\
\hline EL5 & EXPS $_{L}$ & 7.15 & 23.12 & 17.66 & 1.40 & 5.57 & 19.46 & 20.34 & 1.08 \\
\hline EL6 & EXPS & 10.15 & 27.51 & 16.33 & 1.83 & 7.64 & 22.67 & 18.94 & 1.37 \\
\hline EL7 & EXPS & 10.83 & 28.22 & 14.90 & 2.24 & 6.48 & 21.68 & 19.80 & 1.24 \\
\hline EL8 4X & EXPS & 10.76 & 28.33 & 16.28 & 1.94 & 6.74 & 23.04 & 20.12 & 1.30 \\
\hline \multirow[t]{3}{*}{ LSD $5 \%^{2}$} & & 1.21 & 1.40 & 1.13 & 0.23 & 1.68 & 2.09 & 1.82 & 0.31 \\
\hline & \multicolumn{5}{|c|}{ Correlation between sites } & 0.72 & 0.78 & 0.41 & 0.56 \\
\hline & \multicolumn{5}{|c|}{ Probability $\mathrm{P}=$} & 0.0004 & $<0.0001$ & 0.0456 & 0.0074 \\
\hline
\end{tabular}

${ }^{1}$ IBERS, cultivars developed by IGER (UK) for enhanced WSC concentration; NZ, New Zealand cultivars; NZS, New Zealand cultivar with enhanced WSC; EXP, Experimental cultivars; EXPS, Experimental cultivars selected for enhanced WSC; EXPS cultivars selected for low WSC. ${ }^{2}$ Most of the Manawatu data lack true replication. The LSD estimates are derived from an analysis of lines over harvests.

the Canterbury site than the Manawatu site. However, these differences are not significant when the large variations between harvests at each site are taken into account, except possibly for total WSC.

For six of eight harvests in Canterbury, and for the last harvest in Manawatu (the only harvest with replicated data), there was significant variation between entries for fructan and total WSC (data and analyses not shown). For four of eight harvests in Canterbury and the last in Manawatu, crude protein concentrations also varied significantly.

Overall analysis (not shown) of Canterbury data showed significant variation for all three components, with a significant entry-harvest interaction for fructan but not crude protein or total WSC. Analysis of the
Manawatu data showed differences between entries to be consistent across harvests. Without replicated data, there is no test for entry-harvest interaction.

Overall analysis of both sites showed significant differences between entries for all three constituents (Tables 2 and 3 ), though the result is less compelling for crude protein concentration than for the carbohydrate measures. Interaction between entry and site was significant $(\mathrm{P}<0.05)$ for all three, but means and rankings for the two sites were significantly correlated, especially for the carbohydrate measures.

Examination of entry-site means in Table 2 shows clear differentiation between diploid entries selected for enhanced WSC and those which are not, for both the fructan fraction and total WSC. One-way ANOVA 
Table 3 Analyses of variance of line harvest means across two sites (Canterbury and Manawatu), for herbage concentrations of fructan, total water soluble carbohydrate (WSC) and crude protein.

\begin{tabular}{|c|c|c|c|c|}
\hline Fructan & Degrees of Freedom & Mean Square & Variance Ratio & Probability of F parameter \\
\hline entry & 17 & 31.82 & 6.07 & 2.73E-04 \\
\hline site & 1 & 490.64 & 1.59 & 0.23 \\
\hline harvest within site & 16 & 308.95 & 99.85 & $1.58 \mathrm{E}-77$ \\
\hline entry $\mathrm{x}$ site & 17 & 5.24 & 1.69 & 0.044 \\
\hline residual & 272 & 3.09 & & \\
\hline Total & 323 & 21.38 & & \\
\hline \multicolumn{5}{|l|}{ Total WSC } \\
\hline entry & 17 & 70.14 & 8.34 & 3.34E-05 \\
\hline site & 1 & 1573.14 & 5.03 & 0.04 \\
\hline harvest within site & 16 & 312.64 & 67.54 & $6.86 \mathrm{E}-65$ \\
\hline entry $\mathrm{x}$ site & 17 & 8.41 & 1.82 & 0.026 \\
\hline residual & 272 & 4.63 & & \\
\hline Total & 323 & 28.39 & & \\
\hline \multicolumn{5}{|l|}{ Crude protein } \\
\hline entry & 17 & 13.94 & 2.45 & 0.037 \\
\hline site & 1 & 986.42 & 2.45 & 0.14 \\
\hline harvest within site & 16 & 403.15 & 122.99 & $1.72 E-84$ \\
\hline entry $x$ site & 17 & 5.69 & 1.74 & 0.037 \\
\hline residual & 272 & 3.28 & & \\
\hline Total & 323 & 26.82 & & \\
\hline
\end{tabular}

of means for these two components for each site gives significant differentiation $(\mathrm{P}<0.001)$ in each case. Fig. 1 shows fructan concentration harvest means for all diploid entries selected for enhanced WSC (see Table 2 ), compared with all other diploid entries, showing the consistent expression of these differences over sites and harvests.

The cultivars selected for enhanced fructan, had consistently higher concentrations of fructan and total WSC than the standard New Zealand controls, 'Grasslands Impact'and 'Grasslands Samson'. Further, the more recently released 'Abermagic' was consistently superior to the earlier 'Aberdart'. Some tetraploid cultivars, not specifically selected for enhanced fructan, also showed elevated concentrations. However, this was not true in all cases. The new cultivar 'Expo' and some breeding lines, had fructan and total WSC concentrations equalling or superior to 'Aberdart'. 'Expo' was one cultivar with a better mean fructan concentration in Canterbury than in Manawatu, but had the highest values for the trial at the last Manawatu harvest, the only one with replicated samples.

The proportion of total WSC present as fructan did vary, but fructan nevertheless accounted for most interentry variation in total WSC (correlation coefficients within harvests all $>0.75$, most $>0.90$ ). The two were also correlated for harvest means over entries $(\mathrm{r}=0.89, \mathrm{P}<0.001)$.

As for the harvest means, crude protein concentration for entries was generally inversely correlated with carbohydrate concentrations.

\section{Discussion}

The different harvests at the respective sites can not be linked by date or season in any consistent way, with no Manawatu data in late summer or early autumn. The observed increase in fructan and WSC concentrations in November corresponds with the development of stem (defoliated before development beyond 15 or 20 $\mathrm{cm}$ ), where fructan is expected to accumulate (Pollock $\&$ Cairns 1991), but no conclusions can be drawn about differences in mean forage composition between the 
sites or seasons.

Mean WSC concentrations were high and mean crude protein concentrations low, compared to other data (Cosgrove et al. 2007; Dewhurst \& Qiao 2007). Crude protein concentrations were above $25 \%$ for only two harvests in Manawatu, and above 20\% for only two harvests in Canterbury. The mean carbohydrate to protein ratio was always superior to the threshold ratio calculated as critical by Pacheco et al. (2007). The nitrogen fertility management of these trials was moderate $(20 \mathrm{~kg} / \mathrm{ha}$ nitrogen as urea applied after each of up to 8 harvests per year), and in Canterbury the interval between harvests was moderately long (4 weeks during peak growth, longer at other times).

Cultivars selected for enhanced fructan concentrations consistently contained higher concentrations of these compounds than controls. The data are from only two sites and most are for the late winter, spring and early summer seasons. However, the sites are in two contrasting regions and differences were measurable throughout the year. While mean concentrations varied between harvests, the differences between entries were a consistent feature of the data. The mean differences between high and low fructan cultivars varied between harvests (Fig. 1). They were large for all three November harvests, but the differences at other times of the year showed no consistent pattern, except that they were always in the same direction.

This data set shows more consistent expression of enhanced WSC than some others (Hume et al. 2009; Parsons et al. 2004). Statistically significant harvest-entry interactions were observed, but expected differences between entries were always present. The plots were rows rather than swards, and were maintained in a clean state, free of disease and free of reproductive heads. There was no clover present. Sampling was to a controlled height, achieved within a short window in late morning or early afternoon and followed protocols to quickly reduce the temperature of herbage to prevent carbohydrate wastage post-harvest. As noted above, the nitrogen regime was moderate. Environment and management affect WSC concentrations, generally and specifically for cultivar differences (Rasmussen et al. 2009), and differences between entries may have been more difficult to establish in other circumstances or in the face of extraneous variation.

The selected differences between cultivars in fructan concentrations are reflected in total WSC. Variation in fructan concentration accounted for much of the variation in total WSC, and there is no evidence of an offsetting negative correlation with the nonfructan fraction.

For some harvests there was a negative correlation between fructan concentration and total fibre concentration (data not shown). This may reflect successful selection for a greater ratio of cell content to cell wall (but the crude protein concentrations do not reflect this, see below), or a confounding influence of the degree of reproductive development before spike emergence (which would not be expected at an April sampling).

Crude protein concentrations were negatively correlated with concentrations of fructan and total WSC. Crude protein concentrations have been reported to be higher in cultivars selected for high WSC than in controls (Smith et al. 1998), but a negative correlation is more usual (Dewhurst et al. 2007). It has been argued that the carbohydrate to protein ratio is the key parameter in enhanced protein metabolism and a more favourable partition of $\mathrm{N}$ from excretion to production and growth. The negative correlation between crude protein and carbohydrate is helpful in improving the ratio, so that the ratio varies by up to $100 \%$ between entries (Table 2).

The most recently developed IBERS cultivar available in New Zealand, 'Abermagic', was consistently superior in fructan concentration to the earlier cultivar, 'Aberdart'. Likewise, the newly released New Zealand cultivar, 'Expo', is superior to the unselected controls, a result consistent with those obtained under controlled conditions (Rasmussen et al. 2009), and some experimental lines are superior to 'Expo'. This indicates that further enhancements in fructan (and therefore of total WSC and carbohydrate to protein ratio) will be possible.

The questions facing livestock farming and grass breeding teams, are thus, whether grazing systems (with mixed grass-clover swards) can capture production or environmental benefit from enhanced WSC, what target concentrations are likely to be optimal and whether this trait will characterise niche cultivars or become incorporated into the requirements of any modern ryegrass cultivar.

\section{ACKNOWLEDGEMENTS}

NIR analysis was completed by the AgResearch FeedTech laboratory.

\section{REFERENCES}

Beever, D.E. 1993. Ruminant animal production from forages: present position and future opportunities. Proceedings of the XVII International Grassland Congress: 535-542.

Cosgrove, G.P.; Pacheco, D.; Burke, J.L.; Death, A.F.; Hickey, M.J.; Lane, G.A. 2007. Effects of water soluble carbohydrate in forage on aspects of nitrogen partitioning in cows. pp. 350-358. In: Meeting the challenges for pasture-based dairying. Proceedings 
of the 3rd Australasian Dairy Science Symposium. Eds. Chapman, D. F.; Clark, D. A.; Macmillan, K. L.; Nation, D. P. National Dairy Alliance, Melbourne.

Dewhurst, R.J.; Huang, X.; Yibing, N. 2007. Modelling composition targets for high energy dairy pasture. pp. 359-366. In: Meeting the challenges for pasture-based dairying. Proceedings of the 3rd Australasian Dairy Science Symposium. Eds. Chapman, D. F.; Clark, D. A.; Macmillan, K. L.; Nation, D. P. National Dairy Alliance, Melbourne.

Dewhurst, R.J.; Qiao, W. 2007. Relationships between chemical composition and rumen acidogenicity of dairy pasture. pp. 367-372. In: Meeting the challenges for pasture-based dairying. Proceedings of the 3rd Australasian Dairy Science Symposium. Eds. Chapman, D. F.; Clark, D. A.; Macmillan, K. L.; Nation, D. P. National Dairy Alliance, Melbourne.

Edwards, G.R.; Parsons, A.J.; Rasmussen, S. 2007a. High sugar ryegrasses for dairy systems. pp. 307-334. In: Meeting the challenges for pasture-based dairying. Proceedings of the 3rd Dairy Science Symposium. Eds. Chapman, D. F.; Clark, D. A.; Macmillan, K. L.; Nation, D. P. National Dairy Alliance, Melbourne.

Edwards, G.R.; Parsons, A.J.; Rasmussen, S.; Bryant, R. 2007b. High sugar grasses for livestock systems in New Zealand. Proceedings of the New Zealand Grassland Association 69: 161-171.

Hume, D.E.; Hickey, M.J.; Lyons, T.B.; Baird, D.B. 2009. Agronomic performance and water soluble carbohydrate expression of selected ryegrasses at two locations in New Zealand. New Zealand Journal of Agricultural Research: In press.

Humphreys, M.O. 1989. Water-soluble carbohydrates in perennial ryegrass breeding. I. Genetic differences among cultivars and hybrid progeny grown as spaced plants. Grass and Forage Science 44: 231-236.

Lee, M.R.F.; Harris, L.J.; Moorby, J.M.; Humphreys, M.O.; Theodorou, M.K.; MacRae, J.C.; Scollan, N.D. 2002. Rumen metabolism and nitrogen flow to the small intestine in steers offered Lolium perenne containing different levels of water-soluble carbohydrate. Animal Science 74: 587-596.

Lee, M.R.F.; Jones, E.L.; Moorby, J.M.; Humphreys, M.O.; Theodorou, M.K.; MacRae, J.C.; Scollan, N.D. 2001. Production responses from lambs grazed on Lolium perenne selected for an elevated watersoluble carbohydrate concentration. Animal Research 50: 441-449.

Marley, C.L.; Fraser, M.D.; Fisher, W.J.; Forbes, A.B.; Jones, R.; Moorby, J.M.; MacRae, J.C.; Theodorou, M.K. 2007. Effects of continuous or rotational grazing of two perennial ryegrass varieties on the chemical composition of the herbage and the performance of finishing lambs. Grass and Forage Science 62: 255-264.
Merry, R.J.; Lee, M.R.F.; Davies, D.R.; Dewhurst, R.J.; Moorby, J.M.; Scollan, N.D.; Theodorou, M.K. 2006. Effects of high-sugar ryegrass silage and mixtures with red clover silage on ruminant digestion. 1. In vitro and in vivo studies of nitrogen utilization. Journal of Animal Science 84: 3049-3060.

Miller, L.A.; Moorby, J.M.; Davies, D.R.; Humphreys, M.O.; Scollan, N.D.; MacRae, J.C.; Theodorou, M.K. 2001. Increased concentration of water-soluble carbohydrate in perennial ryegrass (Lolium perenne L.). Milk production from late-lactation dairy cows. Grass and Forage Science 56: 383-394.

Moorby, J.M.; Evans, R.T.; Scollan, N.D.; MacRae, J.C.; Theodorou, M.K. 2006. Increased concentration of water-soluble carbohydrate in perennial ryegrass (Lolium perenne L.). Evaluation in dairy cows in early lactation. Grass and Forage Science 61: 52-59.

NIWA 2009. The National Climate Database. http:// cliflo.niwa.co.nz/index.html

Pacheco, D.; Burke, J.L.; Cosgrove, G.P. 2007. An empirical model to estimate efficiency of nitrogen utilisation in cows grazing fresh forages. pp. 409416. In: Meeting the challenges for pasture-based dairying. Proceedings of the 3rd Australasian Dairy Science Symposium. Eds. Chapman, D. F.; Clark, D. A.; Macmillan, K. L.; Nation, D. P. National Dairy Alliance, Melbourne.

Parsons, A.J.; Rasmussen, S.; Xue, H.; Newman, J.A.; Anderson, C.B.; Cosgrove, G.P. 2004. Some 'high sugar grasses' don't like it hot. Proceedings of the New Zealand Grassland Association 66: 265-271.

Pollock, C.J.; Cairns, A.J. 1991. Fructan metabolism in grasses and cereals. Annual Review of Plant Physiology and Plant Molecular Biology 42: 77101.

Rasmussen, S.; Parsons, A.J.; Xue, H.; Newman, J.A. 2009. High sugar grasses - harnessing the benefits of new cultivars through growth management. Proceedings of the New Zealand Grassland Association 71: 167-175.

Smith, K.F.; Simpson, R.J.; Oram, R.N.; Lowe, K.F.; Kelly, K.B.; Evans, P.M.; Humphreys, M.O. 1998. Seasonal variation in the herbage yield and nutritive value of perennial ryegrass (Lolium perenne L.) cultivars with high or normal herbage watersoluble carbohydrate concentrations grown in three contrasting Australian dairy environments. Australian Journal of Experimental Agriculture 38: 821-830.

Taweel, H.Z.; Tas, B.M.; Smit, H.J.; Elgersma, A.; Dijkstra, J.; Tamminga, S. 2005. Effects of feeding perennial ryegrass with an elevated concentration of water-soluble carbohydrates on intake, rumen function and performance of dairy cows. Animal Feed Science and Technology 121: 243-256. 